\title{
Papers from the Institute of Archaeology
}

\section{Microhistory and Archaeology: Some Comments and Contributions}

Artur Ribeiro $^{1, *}$

How to cite: Ribeiro, A. 'Microhistory and Archaeology: Some Comments and Contributions'. Papers from the Institute of Archaeology, 2019, 28(1): pp. 1-26. DOI: $\underline{10.14324 / 111.2041-9015.001}$

Published: 30/04/2019

\section{Peer Review:}

This article has been peer reviewed through the journal's standard double-blind review.

\section{Copyright:}

(C) 2019, The Author(s). This is an Open Access article distributed under the terms of the Creative Commons Attribution License (CC-BY) $4.0 \mathrm{https}: / /$ creativecommons.org/licenses/by/4.0/, which permits unrestricted use, distribution and reproduction in any medium, provided the original author and source are credited • DOI: [https://doi.org/10.14324/111.2041-9015.001].

\section{Open Access:}

Papers from the Institute of Archaeology is a peer-reviewed open access journal. 


\title{
RESEARCH PAPER
}

\section{Microhistory and Archaeology: Some Comments and Contributions}

Artur Ribeiro

\begin{abstract}
Archaeology has always kept an inconsistent relationship with history. For decades, archaeology has either largely rejected what history could offer, such as among certain processual archaeologists, or it has cherry-picked certain elements of historical methods. The closest that archaeologists have ever come to establishing a complete historical method to be applied in archaeology was through the adoption of the idea of the Annales School of history.

Part of what made the Annales School so attractive to archaeologists of all backgrounds was that it tackled the past in a way that was very practical and useful for archaeology: it engaged with the past in the form of total histories, which could then be segmented in three separate durations and could be studied in an interdisciplinary manner. Additionally, the way the Annales School envisaged the past allowed for the study of the past in a very scientific way (e.g. quantitative, statistical), but also allowed the qualitative study of mentalities of the past people under analysis.

However, one of the greatest problems of the Annales School is that it suppressed the human agent. Whether they were hidden behind structural economic forces or long-term symbolic structures, the individual remained always buried under the large-scale - history, according to annalistes, could not be the result of individual action. This, in turn, is what eventually led to the demise of the Annales School, in favour of the Italian microhistory. Does this mean that the Annales School of History must be complete scraped? No, the aim of this paper is to demonstrate that archaeology can in fact have a fruitful historical paradigm based on some ideas of the Annales School, and at the same time, some ideas of Italian microhistory. This would require understanding microhistory as the reconstruction of the life of agents, small-scale case-studies that serve as exemplars of largescale phenomena.
\end{abstract}

Keywords: Archaeology. Microhistory, Archaeological Theory, Annales, Processualism, Postprocessualism

\section{Introduction}

During the rise of postprocessualism, archaeology saw the revival of a historical view in the archaeological discipline. This has brought about the reintroduction of time as a determinant factor in the interpretation of past cultures and the favouring of history 
in explaining social behaviour of past populations. History is to be understood here in the general sense, as research on what men and women did in particular past times and places, and not as the discipline, that is to say, as research on the past based on extant written documentation (Gallie 1964: 51).

At the same time that postprocessualism rose to prominence, there was also change in how history was being practiced outside of archaeology. The slow decline of the Annales School of historical enquiry in France opened the way to a new form of history in the 1980s and 1990s (Hunt 1986). This new school of thought promoted narrative, case-studies, and qualitative research, a rise that had been predicted by Momigliano (1954) and later addressed by Lawrence Stone (1979).

Although archaeology has always tried to rise above itself and become an independent discipline with its own methods, theories, and paradigms, it has generally relied on the theories and ideas provided by other disciplines. The relationship between archaeology and history is no different. For example, in the 1980s and 1990s Ian Hodder and John Bintliff adopted methods and practices that the French Annales School developed from the 1950s to the 1970s. Strangely enough, while Ian Hodder and his postprocessual radical critique denounced the inadequacy of positivist methods that had been the core of processual thought, he was simultaneously adopting the positivist ideas of the Annales School, also known as New History (Hodder 1987a; Hodder \& Hutson 2003). Although the Annales program applied to archaeology has had some fruitful results (e.g. Bintliff 2013; Iannone 2002), some epistemic issues still have yet to be addressed. But before exploring these issues, it is crucial to take a brief look at the relationship between archaeology and history.

\section{History and Archaeology}

\section{Antiquarianism and Culture-History}

The following outline of the history of history in archaeology pertains primarily to the development of archaeological schools of thought in American and British archaeology. Most countries, including a large part of Europe, did not go through a processual phase, much less a postprocessual phase. These countries developed their own schools of thought and practiced archaeology in their own way, regardless of 
the influences that emanated from North America and Britain (Trigger 1996: 31213).

Before archaeology became the discipline it is today, research about past societies was conducted through a series of specialized subjects, such as antiquarianism, classical studies, and ancient history. Antiquarianism, in particular, instituted many of the practices in the 17th and 18th-centuries that were later employed in archaeology, such as the reconstruction of past regional and geographical landscapes and management of artefact collections (Shanks \& Witmore 2010). However, as Glyn Daniel (1963) points out, most antiquarians focused on collecting evidence of past societies with the intent of displaying the beauty of these artefacts and not for scientific purposes (Daniel 1963: 87-88). There was, nevertheless, some connections between antiquarian practices and history, but this connection is somewhat tenuous and inconsistent throughout the history of antiquarianism.

This changed in 19th-century, with the birth of evolutionary theory, and shortly thereafter with the rise of culture-history. One of the most important elements introduced by culture-history was, without a doubt, a more consistent notion of 'culture' and the idea that 'cultures' represented real empirical divisions (Webster 2008:12). Whilst there was some back and forth regarding a working concept of 'culture' in cultural historical studies (Kroeber \& Kluckhohn 1952), the concept of 'history' remained virtually unchanged until the 1940s (Webster 2008: 18). Not much is known regarding how archaeologists made use of history during the first half of the 20th-century, and several authors differ in their ideas on what it truly represented to culture historians. Nevertheless, there seems to be a tacit consensus that the culture-history period is historical only in that it favours historical explanation and historical particularism in its descriptions of past cultures (Piggot 1958; Spaulding 1968; Taylor 1948).

Despite the connections between archaeology and history during the late 19thcentury, the concept of time factored little in understanding the past. This changed when geological stratigraphy (Grayson 1983), and consequently, stratigraphic excavation, became common practice in archaeology. Geological stratigraphy is a practice based on the knowledge disseminated by the work of William Smith, James Hutton, and Georges Lyell. In Europe, stratigraphic excavation came to fruition with the work developed by Pitt Rivers and continued with Flinders Petrie's work in 
Egypt. By 1910, archaeologists had shifted from simply acknowledging the existence of stratigraphic sequences to actually applying a method that would benefit the observation of these sequences (Browman \& Givens 1996). Within the first decades of the 20th-century, archaeologists had a way of measuring time, which along with space, were the two dimensions necessary to situate cultural entities within a framework. However, the way culture-historians engaged with time was somewhat simple, in that time was conceived purely from uni-directional perspective (Lucas 2005). Additionally, time itself served solely as a backdrop where one could place sequences of cultures, best illustrated through maps with arrows flowing from region to region to represent diffusion.

By the late 1950s and early 1960s, the ideas that helped build the culture-historical paradigm lost much of their influence in light of the processual critique. Whereas culture-history failed to coalesce into a uniform body of theory, processual archaeologists started to work on a universal archaeological project aimed at identifying the causes of cultural change. In the eyes of the processual project, archaeology needed to be much more than just reconstruction of cultural histories. It needed to become, as claimed by Binford, the explanation of cultural processes (1968:162).

\section{History and Processual Archaeology}

The ideas propounded by the champion of processual archaeology, Lewis Binford, relegated history to a place where it became unnecessary. In Binford's view, culturehistory's legacy is the description and explication of the diversity of past cultures, a work that Binford considers admirable but clearly insufficient for archaeology. While culture-history focused primarily on denoting past cultures in a particularistic manner (see Kluckhohn 1940 for a critique of this way of conducting archaeological research), Binford argued that this was simply not enough and it was necessary to incorporate 'explanation' into archaeological practice. This attitude led Binford to develop an archaeology with the aim of identifying general laws of human behaviour and to reject all archaeological stances that promote the reconstruction of the past. While history was something that he believed to be of value for the general education of the public, it could not be the ultimate aim of archaeology (Chang 1967: 235). This lack of a historical view is in part the reason why Binford's fieldwork projects largely 
favoured cross cultural analogies. According to his approach, past human behaviour could be inferred by comparison with different time periods and with different cultures $(1962 ; 1978)$. Binford's contributions played a vital role in the development of archaeology in the 20th-century, yet his use of ethnographic analogy for archaeological purposes did not gain widespread praise, as the idea of uniform laws of human behaviour entailed perceiving humans exclusively in terms of biological and environmental constraints. As argued by Hodder (1982a), a coherent understanding of social and cultural behaviour is precluded if following Binford's methods.

While archaeological research in the United States always maintained a strong link to anthropology, in Europe, archaeology remained a relatively independent discipline, with prehistory existing as a subdivision of the history of humanity since the mid19th-century (Daniel 1963: 16). Although not directly linked to anthropology, European archaeology developed its own brand of processual thinking, but it did not include an updated historical perception of the past. Clarke and Renfrew did not subscribe to the idea of universal laws of behaviour (Watson, LeBlanc \& Redman 1972). This notion was found to be too restrictive and impractical for archaeology (Clarke 1973; Renfrew 1973). The rejection of this overly positivistic view would seem to be an acceptance of historical particularism. Though never clearly delineated in European processual thinking, it seemed to say that societies developed according to their exclusive historical conditions.

\section{History and Postprocessual Archaeology}

The radical critique of the postprocessual movement reignited the link between archaeology and history, and this development was studied quite thoroughly by Thomas Patterson (1986; 1989a; 1989b). It is beneficial to review some basic ideas related to postprocessual archaeology that are pertinent to the present effort. The postprocessual critique of the 1980s was a response to the behavioural, functionalist, and positivist ideas developed by the processual school of thought (Preucel 1991; Yoffee \& Sheratt 1993), and it was during the 1980s and 1990s that the postprocessual critique went from being just critique to become diverse strands of approaches from which three main strands of archaeological theory stand out (Patterson 1989b: 556). The first strand, developed by Ian Hodder, is based on the 
work of Collingwood, Barthes, Giddens, Bourdieu, Ricoeur, and Geertz. It argues that the archaeological past is a text, a network of symbols, and the archaeologist's task is to decode and explain this network (Hodder 1982b; Hodder 1985; Hodder 1987a: Hodder 1987b). The second strand can be seen in the work developed by Christopher Tilley and Michael Shanks, which is founded on Michel Foucault's ideas on power and domination and includes Marxist theory to explain late-capitalist influence on how archaeology has developed in the modern world (Miller \& Tilley 1984; Shanks \& Tilley 1987). The third strand, developed in North America through the work of Alison Wylie and Mark Leone, argues for a critical approach to archaeology. It is based on the work developed by the Frankfurt critical school of thought (Leone 1982; Leone 1987; Wylie 1989).

Of these three strands, the one based on the work by Ian Hodder is most pertinent to the topic at hand for two main reasons. First, Hodder (1982a; 1985) rejected the general idea of functionalism and the organicist view of culture, consequently breaking with the Binfordian mould that cultural processes could be generalized (Binford 1962: 218). Furthermore, the idea that cultural processes could not be generalized went hand-in-hand with the idea that explanation does not need to be predicated on universal laws of behaviour (sensu the deductive-nomological approach endorsed by Carl Hempel and Paul Oppenheim (1948)). With the rejection of universal laws of behaviour, the idea of history and historical particularism was once again on the table. While today there are many perspectives on the role of history in archaeology (Cruz Berrocal 2013; Deagan 1988; Deetz 1996; Funari, Jones \& Hall 1999; Leone et al. 1994; Orser 1996; Pauketat 2001; Shackel \& Little 1992), this paper will focus primarily on Ian Hodder's ideas on long-term history (Hodder 1987a, 2000; Hodder \& Hutson 2003), as it is from these ideas that one can work towards some substantive contributions to historical approaches in archaeology.

\section{Archaeology and the Annales Approach}

Although chronological sequences are essential to our understanding of past cultures, chronology itself does not explain nor provide an understanding of what happens between two separate cultural time periods. Thus, isolating 'cultures' gives us a view of the past that is discontinuous, that jumps from one random description to another (Elton 2002 [1969]: 9). When it comes to explanation and understanding, these have 
had different meanings throughout the history of archaeology (Fritz and Plog 1970; Hodder 1982a; Kelley and Hanen 1988; Spaulding 1968; Trigger 1996), but, at a basic level, it can be said that the concepts of explanation and understanding only gain meaning when framed within research questions.

These research questions can be crudely divided into two main groups: 'why' and 'how' questions. Robert Dunnell points out that these two ways of posing questions are designed to illustrate two different aspects of the world: 'how' questions, like 'how does this work?,' pertain primarily to timeless processes where phenomena occur in quite bounded conditions. 'Why' questions, on the other hand, tend to focus primarily on phenomena that are unbound and dependent on prior conditions. In this latter group, an event is a process of becoming and not a result of regular mechanistic processes (Dunnell 1982: 8).

In Ian Hodder's and Scott Hutson's Reading the Past (2003), this distinction is present when he demonstrated why history is partially incompatible with some of the theoretical stances used to interpret archaeological data, many of which portrayed the past in a 'timeless' manner. For instance, Hodder points out that there is an inherent difficulty in understanding and explaining change in structuralist frameworks given that there is no concise explanation of how structures are generated, how they transform, and what actions are associated to them (Hodder \& Hutson 2003: 52-59, 126-127). Furthermore, Hodder also criticized the Marxist view of archaeology, stating that, according to Marxist material culture analysis, it is usually the functionalist viewpoint that is examined, whereas the meaning of the material culture is simply subsumed under 'ideology'.

With this being said, the accusation that structuralist archaeology is 'timeless' (Hodder \& Hutson 2003: 126) can be levelled to Hodder's own work since there is no clear notion of how his study of 'symbols' relates to time. In order to overcome this problem, Hodder adopted Geertz's notion of 'symbolic action' (1973), actions that have signification as main purpose. The concept of 'symbolic action', however, is remarkably opaque. First of all, it seems that symbolic action is nothing more than the conflation of symbolism with instrumentality (Asad 1993: 126), that is to say, the association of thought and practice. As I have argued elsewhere (Arponen and Ribeiro 2014), there is no coherent explanation as to how thoughts give rise to practices. If one accepts that thoughts (symbols) and practices (human action) are distinct, it 
becomes clear why symbolic and structural interpretations of the archaeological record are harder to locate within a time frame, since, without human action, there are no recognizable events that can be associated with symbols or structures. For instance, it can be said that someone went to the bank today or yesterday, but it cannot be said that the symbols associated with banks occurred today or yesterday. This does not mean that symbols are not recognizable through time. Rather, what is lacking is a proper understanding of the process through which symbols are transmitted, changed, and adapted to different empirical realities. Given these issues, several archaeologists have turned to French historians, specifically the historians behind the Annales School of thought and their conception of scale/duration. Like other theoretical trends that have coursed through archaeology, the Annales was adopted by archaeologists when several historians had already exhausted its value and moved on to other ideas (Bintliff 1991:2; Staniforth 1997). However, unlike other trends, the Annales was accepted by both processual and postprocessual archaeologists. By the 1990s, several archaeologists had recognized the full potential of the Annales school (Bintliff 1991; Cobb 1991; Knapp 1992; Last 1995), in particular Braudel's historical structuralism and how it can enrichen the way archaeologists study the past.

While the annalistes developed a wide variety of methods and ideas, the one that seemed most promising to archaeology was the idea of total histories. As the name indicates, total histories comprise very ambitious and comprehensive histories of past societies with Braudel's monumental La Méditerranée et le Monde méditerranéen à l'époque de Pbilippe II (1949) and Pierre Chaunu's Seville et l'Atlantique - 1504 - 1650 (1955) as prime examples. For many annalistes, it was seen as necessary to compile information on the energy sources of these societies as well as their leadership techniques, its notions of time and space, its logistic facilities, and its geography and compare this totality with similar totalities derived from other parts of the world (Harsgor 1978). This idea led many researchers to study whole regions through a plurality of methods, from psychology to genetic studies, sociology, geography, and philosophy, among many others. This wide research spectrum, which mimics Braudel's The Mediterranean, provides several viewpoints that enhances the variables and influences past societies were subject to. 
Another key idea that has been borrowed from Braudel is the division of time into three separate scales, or durations, that are all simultaneous but that affect the course of human development in different wavelengths. The short-term, associated to events, is narratological in form and deals with individuals and overall political history; the medium-term, conjunctures, deals mainly with social and economic history, demography, and history of eras, regions, and societies, and also with world views and ideologies; and finally, the longue durée (long-term), focuses on geohistory and mentalities (Bintliff 1991:6). The ideas and methodologies behind this subdivision of time, the motivation towards interdisciplinary approaches, and the idea of total histories, provide an inexhaustible resource for archaeology, since many of these ideas are fully compatible with how archaeology is practiced (Bintliff 1991; Hodder 1987a; Hodder \& Hutson 2003; Knapp 1992). For instance, the annaliste notion of time scales coheres quite adequately with current holistic trends, which integrate micro-and macro perspectives (e.g. Kristiansen 2014:24). Additionally, many ideals of the Annales School align with those of many archaeological practitioners, namely when it comes to interdisciplinarity. As Braudel (1976) has pointed out, one of the main aims of the Annales was to break down the walls separating disciplines and practice history in collaboration with economics, geography, sociology, linguistics, anthropology, etc. (Braudel 1976:12). Despite the apparent compatibility and the sharing of ideals, there are several problems in applying the methods and approaches of the Annales School in archaeology, which are explored further below.

\section{Limitations of the Annales/Structural Approach}

With its inception in 1929, the Annales school was French historiography's way of adapting to new circumstances, going from a rhetoric and narratological way of making history to a more scientific way. This led to the adoption of an approach that was wholly positivistic, based on facts and serialization, in order to avoid a literaturebased history as it was beforehand. With the Annales, we find a history that rejected "great men" and events spawned by political actions - thus replacing chronological succession with functional and structural principles. Through Braudel and the adoption of the longue durée, the Annales School became linked to different historiographical traditions. Additionally, the longue durée placed seriation and quantitative approaches as the mainstay of the French historical discipline from the 
1950s onwards (Clark 2004). The use of quantitative methods led many historians to believe they could attain true objectivity in their analysis, an idea pursued by some archaeologists during the following decades (Clarke 1973: 9).

A serious issue that came up during the development of the Annales School of history was the fact that they did not really take into consideration philosophical critiques concerning their work, in particular those pertaining to the process of explanation (Clark 2004: 70). While Annales did have considerable influence in France, the historical discipline was not an activity pertaining exclusively to annaliste historians. There were some historians who were aware of the epistemic limitations of history and tried to address this issue. One of these scholars was Henri Marrou. In his essay on historical knowledge, he opens the introductory chapter, aptly named The Critical Philosophy of History (La Philosophie Critique de l'Histoire), by addressing the limitations of truth in history and thus pre-empting the postmodern critique of history by several decades (Marrou 1954: 7). It was, however, with Paul Veyne in the 1970s that the epistemic limitations of the historical discipline, not just the annaliste approach to history, were put out to bare. For Veyne (1984), history was not the lofty discipline the annalistes believed it to be - it was merely a heuristic principle (Veyne 1984: 26), in fact, not even a particularly good principle. These epistemic critiques were largely ignored by annalistes, partly due to the fact that French historiography never held strong links to philosophy and partly due to a certain loosening of the more positivist aspects of the Annales School in later years (Hunt 1986: 215).

But while these general epistemic issues remained largely ignored, criticisms of Braudel's project for history did not go unnoticed. The main problem in Braudel's history concerned the limitations in explaining how large economic and social structures undergo rapid change. As Jacques Revel (1978) pointed out, the Braudelian project was too focused on identifying stable systems while ignoring periods of revolution (Revel 1978:16). A careful look into the output of the Annales School reveals that there was a predominance of essays dedicated to historical periods prior to 1815 , which can be interpreted as an avoidance of subjects associated to rupture and rapid change, subjects where the French school could not compete with the British Marxist School (Hunt 1986).

Moreover, Braudel focused his work primarily on the long and medium durations rather than the short duration, the histoire événementielle. In an effort to distance 
himself from the narrative history that characterized pre-Annales French historiography, he decided to disregard short-term events. In fact, he attacked them with outright hostility (Braudel 1995: 1244). For Braudel, events and individuals are unimportant when faced with the large structures that constrain behaviour (Braudel 1995: 1242). By reducing individuals to mere actors in the background, Braudel's model of durations has failed to attain the objective of linking the long-term mentalités with the short-term events and rapid changes.

This is one of the issues that was transferred to archaeology and remains to this day unsolved. On one hand, there is the historical long-duration and medium-duration, which emphasize constraints in the form of environmental factors, structural forces, and long-term mentalities. On the other hand, there is the actor, who acts in the short-term and is contradictorily constrained and free at the same time (Arkush 2011; Stanton 2004). Braudel's historical project was designed to highlight all of these elements, but it seems clear that it has been unable to portray the agent as actually having any sort of agency - it has served only to emphasize the limitations of human action.

\section{Where is the Historical Agent?}

Producing a daunting work like Braudel's Mediterranean in archaeology should be aspired to, but the truth is that not every researcher has the financial means or even the work ethic of Braudel. Moreover, not all research questions are answerable through total histories. The idea of total history, although extremely appealing, might have to be brought down a couple of notches. If one focuses exclusively on the Braudelian long-term, one will lose sight of the short term, the individual, and the ephemeral. If one focuses exclusively on the short-term, the larger picture, where individual actions can be contextualized, is lost. An ideal solution would be some sort of research dialectic that favours both approaches. Some scholars can work in large scale projects while others can work on the establishment of short-term narratives in smaller projects, but both these groups will actively exchange knowledge.

To this effect, Ian Hodder's work (Hodder \& Hutson 2003) is an excellent synthesis of a historical approach in archaeology. But as pointed out above, Hodder's ideas were quite inconsistent, and these inconsistencies are noticeable in his historical approach. On the one hand, there is Hodder's analysis of meanings, meanings that 
exceed the time scale of an individual life (Hodder \& Hutson 2003: 127), and, on the other hand, Hodder favours the view of the archaeological series of individual events (Hodder 2000). If, as Hodder claims, the structure does not determine the impact of the event, and, if long-term structures cannot be used to explain small events (Hodder \& Hutson 2003: 144) and thus individual actions, what is the relevance of talking about the long-term if there is no correspondence between the archaeological record and long-term meanings?

Hodder contends that long-term meanings are internal and can be found inside events,' but he did not, at the time, realize that what he calls the 'inside of events' does not actually exist on a metaphysical level (Hodder 1987a:2; Hodder \& Hutson 2003: 144). This is a common misconception about the mental life of agents. When it is claimed that an agent acts of his own volition, it is believed that the action springs from inside the agent. As phenomenology has demonstrated, this leads to an incorrect dichotomization of the world - one which separates the internal and the external life of humans (Descombes 1986: 4-5). Believing that there is an 'inside' that motivates behaviour leads to a contradiction in our understanding of how agency operates that humans create internally (mind) what is actually something created by external society (intentional) (Descombes 2001:228-229). This means that the short-term event is not actually a real representation of internalized cultural behaviour, but rather a representation of extant socially institutionalized practices. For example, a person attending mass is not representing what the Church means but what the Church expects of its practitioners.

Segmentations of the past, whether it is through durations or scales, do not accurately reflect mentalities, structures, events, and processes. The long-term does not reflect mentalities any better than the short-term. The long and the short-term are merely different distances from which to observe and describe reality. The experience of time is not segmented (Gell 1992), and it only becomes so when converted to discourse. This is the central problem of both Braudel's and Hodder's understanding of history.

Theories that appeal to the internalization of symbolic behaviour tend to be quite limited in explaining change and, consequently, the passage of time. Attempts at explaining culture change rely primarily on outside factors given that there is no coherent theory of how internalized thought produces change (e.g. Sperber 1996). There is an interdependence of individual events, as human intention, which represent 
the immediate, with the long lasting structures qua institutions that govern practice (Harding 2005). Time is indivisible - the long-term and the short-term are merely forms of discourse and descriptions of the same thing, albeit at different distances. Therefore, studies about the human past must take into account time and history with the small-scale as an exemplar of the long-term. This is, in a way, the basis of microhistory.

\section{Microhistory as Small-Scale History}

In the annaliste school, the favouring of the small-scale came about in the 1970s with Le Roy Ladurie and his Les paysans de Languedoc (1966), Montaillou (1976), and Carnaval de Romans (1979). Le Roy Ladurie took it upon himself to address the issue of the relationships between the short-term event and the long-term, an issue that had haunted the history of the Annales approach since the publication of The Mediterranean. Le Roy Ladurie's work shifted the role the small-scale plays in historical structuralism. Reading Montaillou or Carnaval discloses a perspective that puts 'people' on the forefront, with a focus on how individuals and individual events can and have changed the course of history in a very short period of time. However, Le Roy Ladurie's work is still, in large part, based on traditional Annales ideas and structural history was still a core concept for Ladurie and other late annalistes (Bintliff 1991: 9). Quantification and seriation were still upheld as prime methods and historical structuralism and mentalités as aims.

It was with the publication of Carlo Ginzburg's The Cheese and the Worms (1980), a historical reconstruction of a sixteenth century inquisition trial of a miller's heretical conceptions of the world, that microhistory became known in academic quarters. In the 1980s, we witness the gradual replacement of core Annales practices. First, the third generation of annalistes started endorsing small-scale and research on short-term events. Second, microhistory, with its emphasis on qualitative history and narrative history, started generating a distrust of the overly positivistic methods that had dominated European history since the 1920s.

Microhistory, however, did not have as large of an impact as the Annales School. This was partly because it was never associated to a school of thought as Braudel's work was with the Annales. As Giovanni Levi (1991) claims, microhistory, unlike the Annales School, does not conform to a coherent or specific theoretical posture (97). 
It has been applied since the 1970s by a wide variety of scholars of varying theoretical references, and Ginzburg's work is simply an example of one of the ways of applying microhistorical practice.

For many historians, microhistory is simply a reduced scale of observation, and this seems to be the uniting factor for all microhistorians. The problem with this view is the arbitrariness of the concept of scale - what might be considered 'micro' by some can be considered 'macro' by others, since the scale of observation is relative to the questions that are being asked. But for Giovanni Levi, scale is not in itself the differentiating factor. Reducing the scale of observation answers the need of identifying factors that were previously unobserved, details that elude seriation (Levi 1991: 101). For Ginzburg, quantitative methods force the exclusion of all data that is not statistical or stochastically relevant. A problem arising from serialization is the exclusion of abstract notions, ideas, and beliefs, that defy quantification, but by far the most serious limitation of the quantitative approach is the equalization of all social individuals (Ginzburg 1993: 21). By identifying only what is repetitive, quantitative methods disregard the particularity of history, thus equalizing the masses of population and subsuming them to a structure that limits their capacity for freedom and identity.

Through the observation of the small details that elude quantification, the qualitative aspects of the object of study are brought to the forefront, and these qualitative aspects serve as a sign that represents hidden and obscure underlying ideas (Peltonen 2001:349). These small details and their study is present in most of Ginzburg's work. For this scholar, these details are the evidence that allows the deciphering of the underlying institutions that shape social practice (Ginzburg 1979). It is at this small scale, and possibly only at this scale, that we can truly understand the relationship between the agent and the structural forces that give rise to action (Chartier 1982:32).

\section{Microhistory and Macrohistory - an Alternative to Middle-Range Theory}

When addressing issues of scale - namely that which separates individuals and structural forces - one of the most common methods that is employed is middlerange theory. So, what is the difference between thinking in microhistorical terms and thinking in terms of middle-range theory? Middle-range theory has been a mainstay of archaeological practice since it was first co-opted by Lewis Binford 
(1977, 1981, 1982) from the sociological work of Robert Merton (1968), and its importance is highlighted in archaeology on a regularly basis (Bettinger 1987; Dobres \& Robb 2005; Schiffer 1988; Smith 2011; Trigger 1996:30-42). In archaeology, there are two main discussions concerning middle-range theory. One discussion focuses on the link between the static remains of the present with the dynamic remains of the past, a process that Lewis Binford believed could be solved by middle-range strategies (1981). As Michael Shott (1998) has pointed out, this process should be denoted as 'formation theory' rather than middle-range theory, as Binford did not apply it as Merton originally conceived it. The second discussion reports to the actual use of Mertonian middle-range theory as promoted in archaeology by Michael Schiffer, Robert Bettinger, and Michael Smith.

In this latter discussion, middle-range theory is conceived as a guide to empirical research by serving as an intermediary between general high-range theories of social systems that are too remote from particular cases of social behaviour (Merton 1968: 39). Merton (1968) claims that this is possible. Middle-range 'theories are sufficiently abstract to deal with differing spheres of social behaviour and social structure, so that they transcend sheer description or empirical generalization' (Merton 1968:68). While there are rules as to how empirically adequate statements can be generalized, there are no strict rules as to how an empirical statement can be 'linked' to a high-range theory. In fact, given the vagueness of high-range theories (Bintliff 2011; Ellen 2011), any and every empirical description can somehow be linked to a high-range theory. For instance, 'culture as man's extrasomatic means of adaptation' (Binford 1964: 440) is a propositional statement that can be found in Leslie White's cultural evolutionism theory (White 1959). A proposition of this sort is not empirically adequate, and, as Marvin Harris (1979) points out, not possible to falsify (Harris 1979: 76). If these high-range theories cannot be falsified, it is irrelevant if mid-range theories are empirically adequate. Even if these are falsifiable, the high-range theories remain unchanged. It can be argued, as Harris does, that these high-range theories are not strictly static given that there are constantly refined by the empirical data qua midrange theories (Harris 1979:75), but is this "refinement" not a bit vague and abstract itself? How does Leslie White's cultural evolutionism become more refined through empirical data? These questions cannot have a proper answer, because White's statement is not a description of reality at all, but rather a definition. As demonstrated 
by Gottlob Frege (1951), a statement that claims that 'culture is man's extrasomatic means of adaptation' has to be understood in the same way as ' $2+2=4$ ', where 'is' has the same function as the mathematical '=' sign. This understanding goes against Hodder's idea that archaeological theory is based largely on general claims (1999: 205), for it is, in fact, based primarily on definitions. This is the central problem in middle-range theory. As stated by Boudon (1972), the issue lies not so much in the range of many sociological theories, as in their logical structure' (Boudon 1972: 410, my emphasis).

The middle-range, however, is empirically adequate because the concepts that are being used at this range have adequate referents, which are empirically observable (e.g. cat, man, church, army etc.). Alternatively, the high-range works with concepts that do not have adequate referents. They are abstract concepts and thus are not empirically substantive (e.g. energy, symbol, value, mind, etc.). These high-range concepts are what Henrietta Moore calls concept-metaphors, whose purpose is not to resolve abstraction and ambiguity but to maintain it (Moore 2004: 74). If the highrange and the middle-range do not share common concepts, then it is impossible to connect them. They are simply two groups of independent statements. One group cannot support the other because the concepts in each group are logically different. This is to a large extent why Hodder's long-term archaeology incurred in contradiction: 'symbol', as conceived by Hodder, is a concept-metaphor that has no direct empirical equivalent.

This paper suggests replacing middle-range theory with long-term history and microhistory. Now, it would seem that the same critique above could be levelled to the relation between long-term history and micro small-scale history. Yes, if the longterm is conceived as an over-arching conceptual framework. No, if the long-term is conceived as a distant look at empirical reality.

The difference between high-range and middle-range is one of substance, while the difference between long-term history and microhistory is one of distance. For instance, if Ginzburg's The Cheese and the Worms, which talks about an individual and his trials with the Catholic Church, was incorporated with the history of the Protestant reformation, The Cheese and the Worms could be thought of as a case-study of the intellectual climate during the reformation period. Here, the Protestant reformation is seen on two distinct scales: a macro and a micro one. Moreover, in 
both distances, 'Church' refers to the same institution. Thus, the difference between long-term history and microhistory is one of how close or how far one is looking at its object of enquiry (Ginzburg 2001; Kracauer 2014 [1969]). This is portrayed ingeniously in the novel $W$ ar and Peace, where Leo Tolstoy shifts dramatically from close-up descriptions of actual individual actors to wide panning descriptions of the fate of Russia.

Given the fragmentary nature of the archaeological record, it could be argued that the scale on which microhistorical essays like The Cheese and the Worms are based is precluded in archaeology. Unlike Ginzburg, who had inquisitorial documents to aid him, archaeology relies on a record from which it is much harder to construct a smallscale narrative. However, in archaeology it would not be necessary to go down to a scale as detailed as that of The Cheese and the Worms. It is still possible to address the archaeological at a microscale by focusing on the everyday actions of agents. Furthermore, as has been suggested by Ruth van Dyke, it would be fruitful in archaeology to start thinking in terms of 'imagined narratives' (van Dyke 2015). Her argument can be interpreted as thinking not in terms of what de facto happened to agents in the past, but what were the possibilities available to these agents. This is a central tenet in Ginzburg's own work, which sees historical narrative not so much as generating 'truths' about the past but about seeing historical 'possibilities' (Ginzburg 2012: 55-57).

\section{Conclusion}

Except for the Annales approach, history remains largely ignored in archaeology, whether it is history in terms of a way of understanding (Ribeiro 2018) or whether it is history in terms of methodological approaches. As pointed out by Elizabeth Arkush (2011) and Travis Stanton (2004), it seems archaeology can only follow two models of explanation - one which focuses exclusively on external constraints and another which focuses exclusively on human agency (Arkush 2011, Stanton 2004). Microhistory provides the basis in which both these elements intersect.

Additionally, microhistory provides the element of time, which oftentimes is found lacking in the application of middle-range theory. As pointed out above, definitional statements like White's 'culture is man's extrasomatic means of adaptation' or Hodder's 'material culture is meaningfully constituted' are definitional statements 
and, as such, are 'timeless'. While definitional statements of this sort are, of course, absolutely necessary in archaeology, one should nevertheless be wary of them. Specifically, one should be aware that definitional statements have little to no bearing on the lives of people of past societies. An agent does not use a hammer because it is meaningfully constituted. Rather, an agent uses a hammer because he/she lives in a context in which he/she needs a hammer, and the understanding of this context can be achieved by thinking of past societies in macro and microhistorical terms. For instance, when identifying a hammer in the archaeological record, it is important to think of how craftsmanship, and consequently, professionalization came into existence in recent prehistory and think about crafts and jobs which require hammers. Furthermore, it is also important to think how and why that hammer was used in the specific context of the site that is being studied. In this case, the longterm refers to all the extant social institutions necessary for a hammer to be produced and used, and how these came into existence. The short-term refers to the actual use of a hammer to make a house or a wagon. As Harding puts it,

[t]his is not to contend that the lifetime of an individual is somehow equivalent to the duration of specific social institutions and symbolic schema, but to consider an event, or what is a specific moment of human agency, as the actualisation of a structural pattern situated within a diachronic flow of time. (Harding 2005: 89)

In closing, the aim of this paper was not to provide a systematic historical approach in archaeology, but to provide some groundwork on how archaeology become more attuned to a narrative understanding of the past and to a qualitative way of conducting archaeological research. There are already excellent examples of how microhistorical research in archaeology (e.g. Hupperetz 2010; Kaeser 2008). It remains to be seen how historical thinking in archaeology develops in coming years, and what role microhistory or similar approaches can play.

Acknowledgements: This paper was a side-project while preparing my MA thesis at Institute of Archaeology, UCL, when I was there in 2011-2012. I have to thank all the professors and colleagues who helped me during my stay at the Institute. I would also 
like to thank the help provided by Prof. Johannes Müller, Dr. Martin Furholt, and Dr. Martin Hinz at the University of Kiel. Finally, I appreciate the comments suggestions provided by two anonymous reviewers, and the help provided by the editor, Clare Lewis. All indiscretions and omissions in this paper remain, nevertheless, my own.

Competing Interests: The author declared no potential conflicts of interests with respect to the research, authorship, and/or the publication of this paper.

\section{REFERENCES}

Arkush, E 2011 Explaining the Past in 2010. American Anthropologist, 113(2): 200-212. DOI: http://dx.doi.org/10.1111/j.1548-1433.2011.01324.x

Arponen, V \& Ribeiro, A 2014 Understanding Rituals: A Critique of Representationalism. Norwegian Archaeological Review, 47(2): 161-179. DOI: 10.1080/00293652.2014.938107

Asad, T 1993 Genealogies of Religion: Disciplines and reasons of power in Christianity and Islam. Baltimore, MD: The John Hopkins University Press.

Bettinger, R 1987 Archaeological Approaches to Hunter-Gatherers. Annual Review of Anthropology, 16: 121-142. DOI: http://dx.doi.org/10.1146/annurev.an.16.100187.001005

Binford, L R 1962 Archaeology as Anthropology. American Antiquity, 28(2): 217-225. DOI: http://dx.doi.org/10.2307/278380

Binford, L R 1964 A Consideration of Archaeological Research Design. American Antiquity, 29(4): 425-441. DOI: http://dx.doi.org/10.2307/277978

Binford, L R 1968 Archaeological Perspectives. In; Binford, S R \& Binford, L R New Perspectives in Archaeology. Chicago, IL: Aldine Press. pp. 5-32.

Binford, L R 1977 General introduction. In: Binford, L For Theory Building in Archaeology: Essays on Faunal Remains, Aquatic Resources, Spatial Analysis, and Systemic Modeling. New York, NY: Academic Press. pp. 1-10.

Binford, L R 1978 Nunamiut Ethnoarchaeology. New York, NY: Academic Press.

Binford, L R 1981 Bones: Ancient Men and Modern Myths. New York, NY: Academic Press. 
Binford, L R 1982 Meaning, inference and the material record. In: Renfrew, C, \& Shennan, S Ranking, Resource and Exchange: Aspects of Archaeology of Early European Society. Cambridge: Cambridge University Press. pp. 160-164.

Bintliff, J 1991 The contribution of an Annaliste/structural approach to archaeology. In: Bintliff, J The Annales School and Archaeology. Leicester: Leicester University Press. pp. 1-33.

Bintliff, J 2011 The Death of Archaeological Theory? In: Bintliff, J \& Pearce, M The Death of Archaeological Theory? Oxford: Oxbow Books. pp. 7-22.

Bintliff, J 2013 Modelling long-term social change in the landscape: case-studies from Greece. In: Kalaitzoglu, G \& Lüdorf, G Petasos: Festschrift für Hans Lohmann. Paderborn: Ferdinand Schöningh. pp. 111-118.

Boudon, R 1972 On the underlying epistemology of some sociological theories and on its scientific consequences. Synthese, 24: 410-430. DOI: http://dx.doi.org/10.1007/bf00413655.

Braudel, F 1949 La Méditerranée et le monde méditerranéen à l'époque de Philippe II. Paris: Armand Colin.

Braudel, F 1976 Foreword. In: Stoianovich, T French Historical Method: The Annales Paradigm. Ithaca, NY and London: Cornell University Press. pp. 9-17.

Braudel, F 1995 The Mediterranean and the Mediterranean world in the age of Philip II. Vol. 2. Berkeley, CA and Los Angeles, CA: Berkeley University Press.

Browman, D L \& Givens, D R 1996 Stratigraphic Excavation: The first "New Archaeology". American Anthropologist, 98(1): 80-95. DOI: http://dx.doi.org/10.1525/aa.1996.98.1.02a00080.

Chang, K C 1967 Major aspects of the interrelationship between archaeology and Ethnology. Current Anthropology, 8(3): 227-243. DOI: http://dx.doi.org/10.1086/200795.

Chartier, R 1982 Intellectual history or sociocultural history? The French trajectories. In: LaCapra, D \& Kaplan, S L Modern European intellectual history: Reappraisals and new perspectives. Ithaca, NY: Cornell University Press. pp. 13-46.

Chaunu, P 1955 Seville et L'Atlantique. Paris: A. Colin.

Clark, E 2004 History, theory, text: Historians and the linguistic turn. Cambridge, MA: Harvard University Press.

Clarke, D 1973 Archaeology: the loss of innocence. Antiquity, 48: 6-18.

Cobb, C R 1991 Social Reproduction and the Longue Durée in the Prehistory of the Midcontinental United States. In: Preucel, R Processual and Postprocessual archaeologies: multiple ways of knowing the past. Carbondale, IL: Centre for 
Archaeological Investigations - Southern Illinois University at Carbondale. pp. 168-182.

Cruz Berrocal, M 2013 Archaeology Is (sometimes) History or It Is Nothing: The

Value of History as Critical Archaeology. In: Cruz Berrocal, M, García Sanjuán,

L \& Gilman, A The Prehistory of Iberia: Debating Early Social Stratification. New York, NY and London: Routledge. pp. 29-49.

Daniel, G 1963 The Idea of Prehistory. New York, NY: The World Publishing Company. Deagan, K A 1988 Neither History nor Prehistory: The Questions That Count in

Historical Archaeology. Historical Archaeology, 22(1): 7-12. DOI: http://dx.doi.org/ 10.1007/BF03374494

Deetz, J 1996 In Small Things Forgotten: an archaeology of early American Life. Expanded and Revised Ed. New York, NY: First Anchor Books.

Descombes, V 1986 Objects of all sorts: a philosophical grammar. Oxford: Basil Blackwell. Descombes, V 2001 The Mind's Provisions: A critique of Cognitivism. Princeton, NJ and Oxford: Princeton University Press.

Dobres, M-A \& Robb, J E 2005 "Doing" agency: Introductory remarks on methodology. Journal of Archaeological Method and Theory, 12: 159-166. DOI: http://dx.doi.org/10.1007/s10816-005-6926-z

Dunnell, R C 1982 Science, Social Science, and Common Sense: The Agonizing Dilemma of Modern Archaeology. Journal of Antbropological Research, 38(1): 1-25. Ellen, R 2010 Theories in anthropology and "anthropological theory". Journal of the Royal Anthropological Institute, 16(2):387-404. DOI: http://dx.doi.org/10.1111/j.1467-9655.2010.01631.x

Elton, G 2002 [1969] The Practice of History. 2nd ed. Oxford: Blackwell. Frege, G 1951 On Concept and Object. Mind, 60(238): 168-180.

Fritz, J \& Plog, F 1970 The nature of archaeological explanation. American Antiquity, 35: 405-412. DOI: http://dx.doi.org/10.2307/278113

Funari, P P A, Jones, S \& Hall, M 1999 Introduction. Archaeology in History. In: Funari, P P A, Hall, M \& Jones, S Historical Archaeology: Back from the Edge. London and New York, NY: Routledge. pp. 1-20.

Gallie, W B 1964 Pbilosophy and the Historical Understanding. London: Chatto and Windus.

Geertz, C 1973 The Interpretation of Cultures: Selected Essays. New York, NY: Basic Books.

Gell, A 1992 The Anthropology of Time: Cultural constructions of temporal maps and images. Oxford: Berg. 
Ginzburg, C 1979 Clues. Theory and Society, 7(3): 273-288. DOI: http://dx.doi.org/10.1007/bf00207323

Ginzburg, C 1980 The Cheese and the Worms: The cosmos of a sixteenth century miller. London: Routledge.

Ginzburg, C 1993 Microhistory: two or three things I know about it. Critical Inquiry, 20(1): 10-35. DOI: http://dx.doi.org/10.1086/448699

Ginzburg, C 2001 Wooden Eyes: Nine Reflections on Distance. New York, NY: Columbia University Press.

Ginzburg, C 2012 Threads and Traces: True False Fictive. Berkeley, CA: University of California Press.

Grayson, D K 1983 The Establishment of Human Antiquity. New York, NY: Academic Press.

Harding, J 2005 Rethinking the Great Divide: Long-Term Structural History and the Temporality of Event. Norwegian Archaeological Review, 38(2): 88-101. DOI: http://dx.doi.org/10.1080/00293650510032707

Harris, M 1979 Cultural Materialism: The Struggle for Science of Culture. New York, NY: Random House.

Harsgor, M 1978 Total History: The Annales School. Journal of Contemporary History, 13: 1-13. DOI: http://dx.doi.org/10.1177/002200947801300101

Hempel, C G \& Oppenheim, P 1948 Studies in the Logic of Explanation. Philosophy of Science, 15(2): 135-175. DOI: http://dx.doi.org/10.1086/286983

Hodder, I 1982a Theoretical archaeology: a reactionary view. In: Hodder, I Symbolic and Structural archaeology. Cambridge: Cambridge University Press. pp. 1-16. DOI: http://dx.doi.org/10.1017/cbo9780511558252

Hodder, I 1982b Symbols in Action: Ethnoarchaeological Studies of Material Culture. Cambridge: Cambridge University Press.

Hodder, I 1985 Postprocessual archaeology. In: Schiffer, M Advances in archaeological method and theory. Orlando, FL: Academic Press. pp 1-26. DOI: http://dx.doi.org/10.1016/b978-0-12-003108-5.50006-3

Hodder, I 1987a The contribution of the long term. In: Hodder, I Archaeology as long term history. Cambridge: Cambridge University Press. pp. 1-8.

Hodder, I 1987b The contextual analysis of symbolic meanings. In: Hodder, I The archaeology of contextual meanings. Cambridge: Cambridge University Press. pp. 110.

Hodder, I 1999 The Archaeological Process: An Introduction. Oxford and Malden: Blackwell Publishers. 
Hodder, I 2000 Agency and Individuals in Long-term processes. In: Dobres, M-A \& Robb, J Agency in Archaeology. London and New York, NY: Routledge. pp. 2133. DOI: http://dx.doi.org/10.4324/9781315866000

Hodder, I \& Hutson, S 2003 Reading the Past: Current Approaches to Interpretation in Archaeology. 3rd ed. Cambridge: Cambridge University Press.

Hunt, L 1986 French History in the Last Twenty Years: The Rise and Fall of the Annales Paradigm. Journal of Contemporary History, 21(2): 209-224. DOI: http://dx.doi.org/10.1177/002200948602100205

Hupperetz, W 2010 Micro history, archaeology and the study of housing culture. Some thoughts on archaeological and historical data from a cesspit in 17thcentury Breda. In: De Groote, K, Tys, D, \& Pieters, M Exchanging Medieval Material Culture: Studies on archaeology and history presented to Frans Verhaeghe. Brussels: Vlaams Instituut voor het Onroerend Erfgoed. pp. 279-284.

Iannone, G 2002 Annales History and the Ancient Maya State: Some Observations on the "Dynamic Model". American Anthropologist, 104(1): 68-78. DOI: http://dx.doi.org/10.1525/aa.2002.104.1.68

Kaeser, M-A 2008 Biography as microhistory. In: Schlanger N Archives, Ancestors, Practices: archaeology in the light of its history. New York, NY and Oxford: Berghahn. pp. 9-20.

Kelley, J \& Hanen, M 1988 Archaeology and the Methodology of Science. Albuquerque, NM: University of New Mexico Press.

Knapp, A B 1992 Archaeology, Annales, and Ethnohistory. Cambridge: Cambridge University Press. DOI: http://dx.doi.org/10.1017/cbo9780511759949.

Kracauer, S 2014 [1969] History: The Last Things before the Last. Princeton, NJ: Markus Wiener Publishers.

Kristiansen, K 2014 Towards a New Paradigm? The Third Science Revolution and its Possible Consequences in Archaeology. Current Swedish Archaeology, 22: 11-34.

Kluckhohn, C 1940 The Conceptual Structure in Middle American Studies. In: Hay, C, Linton, R, Lothrup, S, Shapiro, H, \& Caillant, G The Maya and their Neighbors. New York, NY: Dover. pp. 41-51.

Kroeber, A \& Kluckhohn, C 1952 Culture: a critical review of concepts and definitions. New York, NY: Vintage Books.

Ladurie, E le R 1966 Les paysans de Languedoc. Paris: Flammarion.

Ladurie, E le R 1976 Montaillou: village Occitan de 1294 à 1324. Paris: Gallimard.

Ladurie, E le R 1979 Le Carnaval de Romans. Paris: Gallimard. 
Last, J 1995 The Nature of History. In: Hodder, I, Shanks, M, Alexandri, A, Buchli, V, Carman, J, Last, J \& Lucas, G Interpreting Archaeology: Finding Meaning in the Past. London and New York, NY: Routledge. pp. 141-157.

Levi, G 1991 On Microhistory. In: Burke, P New Perspectives on Historical Writing. Cambridge: Polity Press. pp. 97-119.

Leone, M 1982 Some opinions about recovering mind. American Antiquity, 47(4): 742760. DOI: http://dx.doi.org/10.2307/280280

Leone, M 1987 Toward a critical archaeology. Current Anthropology, 28(3): 283-292. DOI: http://dx.doi.org/10.1086/203531

Leone, M P, Mullins, P R, Creveling, M C, Hurst, L, Jackson-Nash, B, Jones, L D, ... Warner, M S 1994 Can an African-American historical archaeology be an alternative voice? In: Hodder, I, Shanks, M, Alexandri, A, Buchli, V, Carman, J, Last, J \& Lucas, G Interpreting Archaeology: Finding Meaning in the Past. London and New York, NY: Routledge. pp. 110-124.

Marrou, H-I 1954 De la connaisance historique. Paris: Editions du Seuil.

Merton, R 1968 Social Theory and Social Structure. New York, NY: The Free Press.

Miller, D \& Tilley, C 1984 Ideology, power and prehistory: an introduction. In: Miller, D \& Tilley, C Ideology, power and prehistory. Cambridge: Cambridge University Press. pp. 1-15. DOI: http://dx.doi.org/10.1017/cbo9780511897443

Momigliano, A 1954 An unsolved problem of historical forgery: The scriptores Historiae Augustae. Journal of the Warburg and Courtauld Institute, 17(1/2): 22-46. DOI: http://dx.doi.org/10.2307/750131

Moore, H 2004 Global Anxieties: concept-metaphors and pre-theoretical commitments in anthropology. Anthropological Theory, 4(1): 71-88. DOI: http://dx.doi.org/10.1177/1463499604040848.

Orser, C E 1996 A Historical Archaeology of the Modern World. New York, NY: Springer. Patterson, T 1986 The last sixty years: towards a social history of Americanist archaeology in the United States. American Antbropologist, 88(1): 7-26. DOI: http://dx.doi.org/10.1525/aa.1986.88.1.02a00010

Patterson, T 1989a Post-structuralism, post-modernism: implications for historians. Social History, 14: 83-88. DOI: http://dx.doi.org/10.1080/03071028908567727

Patterson, T 1989b History and the Post-Processual Archaeologies. Man. New Series, 24(4): 555-556. DOI: http://dx.doi.org/10.2307/2804287

Pauketat, T 2001 Practice and History in Archaeology: An Emerging Paradigm. Anthropological Theory, $1(1)$ : 73-98. DOI: http://dx.doi.org/10.1177/146349960100100105 
Peltonen, M 2001 Clues, Margins, and Monads: The Micro-Macro link in historical research. History and Theory, 40(3): 347-359. DOI: http://dx.doi.org/10.1111/0018-2656.00172

Piggott, S 1958 Approach to Archaeology. London: Adam \& Charles Black.

Preucel, R 1991 Introduction. In: Preucel, R Processual and Postprocessual archaeologies: multiple ways of knowing the past. Carbondale, IL: Centre for Archaeological Investigations - Southern Illinois University at Carbondale. pp. 1-14.

Renfrew, C 1973 Explanation revisited. In: Renfrew, C, Rowlands, M, \& Segraves, B Theory and Explanation in Archaeology. New York, NY: Academic Press. pp. 5-24. Revel, J 1978 The Annales: Continuities and Discontinuities. Review, 1(3/4): 9-18.

Ribeiro, A 2018 Archaeology and the Historical Understanding. Bonn: Dr. Rudolf Habelt Verlag.

Schiffer, M 1988 The structure of archaeological theory. American Antiquity, 53(3): 461-485. DOI: http://dx.doi.org/10.2307/281212

Shackel, P A \& Little, B J 1992 Post-Processual Approaches to Meanings and Uses of Material Culture in Historical Archaeology. Historical Archaeology, 26: 5-11. DOI: http://dx.doi.org/10.1007/BF03373538

Shanks, M \& Tilley, C 1987 Re-constructing Archaeology: theory and practice. Cambridge: Cambridge University Press.

Shanks, M \& Witmore, C 2010 Echoes across the Past: Chorography and topography in antiquarian engagements with place. Performance Research, 15(4): 97-106. DOI: 10.1080/13528165.2010.539888

Shott, M J 1998 Status and role of formation theory in contemporary archaeological practice. Journal of Archaeological Research, 6(4): 299-329.

Smith, M E 2011 Empirical Urban Theory for Archaeologists. Journal of Archaeological Method and Theory, 18(3): 167-192. DOI: http://dx.doi.org/10.1007/s10816010-9097-5

Spaulding, A 1968 Explanation in Archaeology. In: Binford, L \& Binford, S New Perspectives in Archaeology. Chicago, IL: Aldine Publishing Company. pp. 33-39.

Sperber, D 1996 Explaining Culture: a naturalistic approach. Oxford: Blackwell Publishing.

Staniforth, M 1997 The Archaeology of the Event - The Annales School and Maritime Archaeology. Underwater Archaeology: 17-21.

Stanton, T W 2004 Concepts of determinism and free will in archaeology. Anales de Antropología, 38(1): 29-83.

Stone, L 1979 The Revival of Narrative: Reflections on a New Old History. Past and Present, 85: 3-24. DOI: http://dx.doi.org/10.1093/past/85.1.3 
Taylor, W W 1948 A Study of Archaeology. Illinois: Southern Illinois University Press. Trigger, B 1996 A History of Archaeological Thought. 2nd ed. Cambridge: Cambridge University Press. DOI: http://dx.doi.org/10.1017/cbo9780511813016

van Dyke, R M 2015 The Chacoan Past: Creative Representations and Sensory Engagements. In: Van Dyke, R M \& Bernbeck, R Subjects and Narratives in Archaeology. Boulder, CO: University Press of Colorado. pp. 83-99. DOI: http://dx.doi.org/10.5876/9781607323815.c004

Veyne, P 1984 Writing History: Essay on Epistemology. Middletown, CT: Wesleyan University Press.

Watson, P J , Leblanc, S, \& Redman, C 1971 Explanation in Archaeology: An explicitly scientific approach. New York, NY: Columbia University Press.

Webster, G S 2008 Culture History: A Culture-Historical Approach. In: Bentley, R A, Maschner, H, \& Chippindale, C Handbook of Archaeological Theories. Plymouth, MA: Altamira Press.

White, L 1959 The Evolution of Culture. New York, NY: McGraw Hill.

Wylie, A 1989 Matters of fact, matters of interest. In: Shennan, S Archaeological approaches to cultural identity. London: Unwyn and Hyman. pp. 94-109. DOI: http://dx.doi.org/10.4324/9780203163740

Yoffee, N \& Sherratt, A 1993 Introduction: the sources of archaeological theory. In: Yoffee, N \& Sherratt, A Archaeological theory: who sets the agenda? Cambridge: Cambridge University Press. pp. 1-9. DOI: http://dx.doi.org/10.1017/CBO9780511720277 